$\mathrm{K}$

\title{
ZASADA POSZANOWANIA AUTONOMII I WZAJEMNEJ NIEZALEŻNOŚCI PAŃSTWA I KOŚCIOŁÓW ORAZ INNYCH ZWIĄZKÓW WYZNANIOWYCH W ORZECZNICTWIE TRYBUNAŁU KONSTYTUCYJNEGO
}

\section{Streszczenie}

W artykule przedstawiono analizę orzecznictwa Trybunału Konstytucyjnego w zakresie zasady poszanowania autonomii i wzajemnej niezależności państwa i kościołów oraz innych związków wyznaniowych. W pierwszej kolejności została przedstawiona proweniencja tej zasady. W szczególności wskazano na jej aspekt komparatystyczny. Następnie przedstawiono tę zasadę jako element relacji pomiędzy państwem i związkami wyznaniowymi w ujęciu judykatury Trybunału Konstytucyjnego. W kolejnych częściach artykułu przedstawiono wykładnię tej zasady oraz jej zakres w orzecznictwie Trybunału Konstytucyjnego. Najważniejsze wnioski przedstawiono w zakończeniu.

Słowa kluczowe: autonomia; niezależność; wolność religijna; relacje państwo-kościół; współdziałanie państwa i kościoła

$$
* * * * *
$$

\section{WSTĘP}

Zasada poszanowania autonomii i wzajemnej niezależności państwa i kościołów oraz innych związków wyznaniowych każdego w swoim zakresie ${ }^{1}$ została uznana przez prawodawcę $\mathrm{w}$ wymiarze generalnym

* Dr, Katedra Prawa Polskiego i Międzynarodowego, Wydział Prawa Kanonicznego, Uniwersytet Kardynała Stefana Wyszyńskiego w Warszawie, ul. Dewajtis 5, 01-815 Warszawa, e-mail: michal.poniatowski@adwokatura.pl. ORCID 0000-0002-7263-4550.

1 Dalej: zasada poszanowania autonomii i niezależności. 
w art. 25 ust. 3 Konstytucji ${ }^{2}$ oraz odpowiednio w wymiarze dwustronnym w art. 1 Konkordatu ${ }^{3}$, stanowiąc tym samym element prawa konstytucyjnego oraz międzynarodowego. Zasada ta stanowi również element ustroju państwa, o czym świadczy choćby umieszczenie jej w Rozdziale I Konstytucji („Rzeczpospolita”). Tym samym powinna ona być przedmiotem interpretacji dokonywanej nie tylko przez przedstawicieli doktryny prawa konstytucyjnego i prawa wyznaniowego, której syntezie można poświęcić oddzielne opracowanie, ale również przez Trybunał Konstytucyjny. To właśnie analiza jego dotychczasowego orzecznictwa w tym zakresie - zarówno bezpośrednio, jak i pośrednio odnoszącego się do tej zasady - będzie przedmiotem niniejszego artykułu.

\section{PROWENIENCJA ZASADY POSZANOWANIA AUTONOMII I NIEZALEŻNOŚCI}

Analiza orzecznictwa Trybunału Konstytucyjnego wymaga, aby w pierwszej kolejności pokazać tło uznania tej zasady, w szczególności podczas prac nad projektem Konstytucji. W doktrynie odnaleźć można wiele szczegółowych opracowań lub ich części poświęconych temu zagadnieniu ${ }^{4}$. Z uwagi na ramy niniejszego artykułu można w dużym uproszczeniu wskazać, że określenie relacji państwa i związków wyznaniowych było jedną z głównych dyskusji toczonych nad kształtem Konstytucji. Proponowano różne, wręcz skrajne, modele tych relacji i ostatecznie przyjęto

2 Konstytucja Rzeczypospolitej Polskiej z dnia 2 kwietnia 1997 r., Dz. U. z 1997 r. $\mathrm{Nr} 78$, poz. 483. z późn. zm.

3 Konkordat między StolicąApostolską a Rzecząpospolitą Polskąz dnia 28 lipca 1993 r., Dz. U. z 1998 r. Nr 51, poz. 318. Zgodnie z art. 1 Konkordatu: „Rzeczpospolita Polska i Stolica Apostolska potwierdzają, że Państwo i Kościół Katolicki są - każde w swej dziedzinie niezależne i autonomiczne oraz zobowiązują się do pełnego poszanowania tej zasady we wzajemnych stosunkach i we współdziałaniu dla rozwoju człowieka i dobra wspólnego". Na różnice w zakresie stopnia ogólności tych norm zwraca uwagę m.in. J. Krukowski. Por. Krukowski 2019, 178.

4 Por. Borecki 2002; tenże 2008; tenże 2004, 49-66; Krukowski 1993, 319-330; Leszczyński 2014, 19-43; tenże 1993, 281-299; Pietrzak 1997, 104-126; Sobczyk 2004, 859-887; Zieliński 1997, 81-98. 
takie brzmienie tej zasady, które odnaleźć można również w prawie kanonicznym, o czym warto pamiętać dokonując analizy przedmiotowej zasady. Jej istota została sformułowana blisko dwa tysiące lat temu stanowiąc fundament tzw. dualizmu religijno-politycznego ${ }^{5}$.

W ujęciu komparatystycznym należy zwrócić uwagę, że choć proklamacja tej zasady expressis verbis miała miejsce podczas obrad Soboru Watykańskiego II, to funkcjonowania przedmiotowej zasady w prawie kanonicznym upatruje się już od początku istnienia Kościoła ${ }^{6}$. Jej istotę odnaleźć można chociażby w słowach Jezusa Chrystusa: „Oddajcie więc Cezarowi to, co należy do Cezara, a Bogu to, co należy do Boga"7. W sferze prawa kanonicznego słowa te stanowią przedmiot ciągłej interpretacji, począwszy od Apostołów, pierwszych chrześcijan, papieży, Ojców i Doktorów Kościoła, jak również soborów powszechnych, w tym Vaticanum II $^{8}$. Istota tej zasady była rozważana m.in. przez wielu papieży, w tym była przedmiotem słynnej formuły galezjańskiej, włączonej następnie do Kodeksu Justyniana. Co ciekawe, Trybunał Konstytucyjny w jednym z orzeczeń w wywodzie prawnym powołał się na ten kodeks, choć już w innym kontekście ${ }^{9}$. Warto jednak zauważyć, że w orzecznictwie Trybunału Konstytucyjnego można odnaleźć powoływanie się na prawo kanoniczne jako implicite elementu europejskiej kultury prawnej ${ }^{10}$. Tym bardziej dorobek

5 Por. Poniatowski 2014, 211.

6 Por. Krukowski 2013, 135.

7 Mt 22, 15-22. Por także Mk 12, 13-17, Łk 20, 20-26.

8 Por. Poniatowski 2014, 211-237.

9 Zgodnie z wyrokiem Trybunału Konstytucyjnego z dnia 8 marca 2005 r. K 27/03 (Dz. U. z 2005 r. Nr 41, poz. 401; OTK ZU z 2005 r. Nr 3A, poz. 22; Legalis nr 67390): „Zasada niedziałania prawa wstecz była wielokrotnie przedmiotem rozważań Trybunału Konstytucyjnego. Przekrojowej analizy wcześniejszego orzecznictwa odnoszącego się do zasady lex retro non agit Trybunał dokonał w wyroku z 3 października 2001 r. (sygn. K 27/01, OTK ZU nr 7/2001, poz. 209). W orzeczeniu tym Trybunał przypomniał, że zasada ta, będąca istotnym elementem systemów prawnych współczesnych państw demokratycznych, ma swoje korzenie w starożytności. W prawie rzymskim funkcjonowała już na gruncie Kodeksu Justyniana. W polskim porządku prawnym zasada lex retro non agit była przywołana już w XIV w. Była uznaną zasadą systemu prawnego II Rzeczypospolitej”.

10 Na podstawie wyroku Trybunału Konstytucyjnego z dnia 3 października 2001 r., K 27/01 (M. P. z 2001 r. Nr 45, poz. 739; OTK ZU z 2001 r. Nr 7, poz. 209; Legalis nr 50909): „Trybunał Konstytucyjny podkreśla, że zasada lex retro non agit, będąca obec- 
kanonistyki - zawierający argumentację nieposiadającą charakteru teologicznego - może być pomocny także w państwie świeckim dla właściwej interpretacji tej zasady w polskim porządku prawnym, w tym tej dokonywanej przez Trybunał Konstytucyjny, w szczególności w zakresie ustalenia przedmiotu autonomii i niezależności Kościoła i państwa czy też wyprowadzenia tej zasady również z aksjologicznej koncepcji godności osoby ludzkiej i wynikającej z niej wolności religijnej. Jak dotychczas Trybunał Konstytucyjny nie odniósł się jednak bezpośrednio do tego dorobku w kontekście zasady poszanowania autonomii i niezależności.

W perspektywie działalności orzeczniczej Trybunału Konstytucyjnego powinno mieć znaczenie także to, że przedmiotowa zasada nie ma charakteru incydentalnego i została uznana w kilkunastu współczesnych konstytucjach i kilkudziesięciu współczesnych konkordatach ${ }^{11}$. W szczególności należy zwrócić uwagę, że jest ona uznawana explicite albo implicite w konkordatach zawieranych z państwami, zarówno tymi, które kiedyś miały charakter katolickich państw wyznaniowych (np. Włochy ${ }^{12}$, Portugalia ${ }^{13}$ ), ale także państwami bez takiej tradycji, w tym państwami świe-

nie istotnym elementem kultury prawnej współczesnych państw cywilizowanych, a także zasadniczym składnikiem porządku konstytucyjnego współczesnych ustrojów konstytucyjnych, ma swoje korzenie w prawie rzymskim. W systemie prawa rzymskiego funkcjonuje wprawdzie nie tak dosłownie nazywana - już w Kodeksie Justyniana (księga 1, tytuł 14, lex 7 oraz księga 6, tytuł 5, lex 12). W średniowieczu pojawia się także w prawie kanonicznym (np. Clementinae z 1317 r.). Jest godne podkreślenia, że w polskim porządku prawnym zasada lex retro non agit pojawia się już w XIV wieku wraz z ustanowieniem statutów Kazimierza Wielkiego Cum omnes constitiones et statuta legem imponant rebus et negotis presentibus et futuris et non preteritis. Od tego czasu ta zasada stała się trwałym elementem polskiego systemu prawnego. Znajduje ona nieocenione zastosowanie zarówno w porządku prawnym I jak i II Rzeczypospolitej. Dlatego też już od początku swego orzecznictwa Trybunał odwoływał się do bogatego dorobku intelektualnego polskiej doktryny prawa, co do rozumienia zasady lex retro non agit i jej miejsca w systemie naczelnych zasad ustrojowych Rzeczypospolitej".

11 Por. Němec 2011; Poniatowski 2012.

12 Accordo tra la Santa Sede e la Repubblica Italiana che apporta modificazioni al Concordato Lateranense (18.02.1984), AAS 77 (1985), s. 521-535.

13 Conventio inter Apostolicam Sedem et Rem Publicam Lusitanam (18.05.2004), AAS 97 (2005), s. 29-50. 
ckimi (np. Albania ${ }^{14}$, Chiny ${ }^{15}$ ), a nawet niechrześcijańskimi państwami wyznaniowymi (np. Maroko $\left.{ }^{16}\right)^{17}$. Jak trafnie wskazuje P. Stanisz, poszanowanie autonomii związków wyznaniowych można dziś uznać za wiążący europejski standard ${ }^{18}$. Można wręcz dojść do wniosku, że zasada ta stanowi pewien standard prawa konstytucyjnego oraz międzynarodowego ${ }^{19}$.

Uznanie tej zasady w Konstytucji z 1997 r. stanowiło element przebudowy modelu relacji państwa i związków wyznaniowych. W orzecznictwie Trybunału Konstytucyjnego odnaleźć można odniesienie do okresu transformacji w aspekcie wyznaniowym. Zgodnie z wyrokiem Trybunału Konstytucyjnego z dnia 2 grudnia 2009 r.: „W okresie od uchwalenia ustaw z 17 maja 1989 r., a zwłaszcza ustawy o gwarancjach, do czasu uchwalenia nowej Konstytucji z 2 kwietnia 1997 r., dokonywała się przebudowa dotychczasowego modelu stosunków między państwem a kościołami i związkami wyznaniowymi. Następowała przebudowa polegająca na odchodzeniu od skrajnego modelu państwa świeckiego, oddzielonego od kościołów, zmierzającego ku pełnej laicyzacji - ku szerokiej formule państwa świeckiego gwarantującego demokratyczne standardy wolności sumienia i wyznania w warunkach pluralizmu, neutralności i bezstronności państwa wobec religii, gwarantującego również nauczanie religii w szkołach publicznych"20. Zasada poszanowania autonomii i niezależności jako element Konstytucji z 1997 r. została zatem pośrednio przeciwstawiona skrajnemu modelowi państwa świeckiego.

W powyższym wyroku Trybunał Konstytucyjny zauważył kilka istotnych zmian w okresie tej przebudowy, która miała charakter stopniowy.

14 Conventio inter Sedem Apostolicam et Rem Publicam Albaniae de mutuis moderandis necessitudinibus (23.03.2002), AAS 94 (2002), s. 660-664.

15 Conventio inter Apostolicam Sedem et Rem Publicam Sinarum de cooperatione in campo superioris institutionis ac de recognitione studiorum, qualitatum, diplomatum et graduum (2.12.2011), AAS 105 (2013), s. 93-104.

16 Litterae mutuo datae a Serenissimo Principe Hassan II, Rege Marochii, et a Ioanne Paulo II, Summo Pontifice: de Statuto Ecclesiae Catholicae in Marochio (30.12.1983), AAS 77 (1985), s. 712-715.

17 Por. Poniatowski 2012, 155-175; tenże 2016, 88-109.

18 Por. Stanisz 2015, 163.

19 Por. Poniatowski 2016, 102.

20 Wyrok Trybunału Konstytucyjnego z dnia 2 grudnia 2009 r., U 10/07 (Dz. U. z 2009 r. Nr 210, poz. 1629; OTK ZU z 2009 r. Nr 11A, poz. 163; Legalis nr 178953). 
Po pierwsze Trybunał Konstytucyjny zauważył zmianę pojęcia państwa świeckiego w okresie powyższej przebudowy: „Na kształt wyłaniającego się nowego typu relacji między państwem a kościołami, mieszczącego się nadal w szerokim, współczesnym modelu państwa świeckiego, w którym jednak termin «państwo świeckie» traci swoją pierwotną ostrość i jednoznaczność, oraz na treść szeroko pojętej wolności sumienia i wyznania wpływały w tym okresie w szczególności: ustawy wyznaniowe z 17 maja 1989 r., konstytucyjne zmiany ustrojowe, a w szczególności obowiązująca od 1 stycznia 1990 r. konstytucyjna zasada demokratycznego państwa prawnego, ale także tradycje, układ społecznych stosunków wyznaniowych i pozycja Kościoła katolickiego. W sferze politycznej istotne znaczenie miała dokonująca się zmiana układu sił politycznych (w parlamencie, w rządzie). Te czynniki przesądziły o kształcie, jaki przybrała konstytucyjna regulacja wolności sumienia i wyznania w Konstytucji z 1997 r. w ramach wspomnianej szerokiej, pojemnej idei wolności sumienia i wyznania, wynikającej ze współczesnych standardów demokratycznego, pluralistycznego społeczeństwa, standardów wskazanych wyżej, w świetle najważniejszych aktów międzynarodowych i orzecznictwa Europejskiego Trybunału Praw Człowieka"21. Tym samym zmiana typu relacji między państwem a związkami wyznaniowymi miała charakter złożony. W szczególności należy zwrócić uwagę, że w rozumieniu Trybunału Konstytucyjnego nastąpiło odejście od ostrego i jednoznacznego pojęcia państwa świeckiego w kierunku szerokiego modelu współczesnego państwa świeckiego.

W ocenie Trybunału Konstytucyjnego szczególne znaczenie w kształtującym się w Rzeczypospolitej Polskiej nowym modelu stosunków między państwem a kościołami i innymi związkami wyznaniowymi miało ratyfikowanie Konkordatu po kilkuletniej dyskusji oraz sporach politycznych $^{22}$. W konsekwencji to szczególne znaczenie ratyfikacji Konkordatu odnosi się również do zrozumienia dotychczasowego pojęcia państwa świeckiego, albowiem jak wskazał Trybunał Konstytucyjny: „Wraz z ratyfikacją konkordatu ewoluowało znaczenie normatywne pojęcia «państwa świeckiego», zamieszczonego w art. 10 ust. 1 ustawy o gwarancjach, sta-

21 Wyrok Trybunału Konstytucyjnego z dnia 2 grudnia 2009 r., U 10/07.

22 Por. tamże. 
nowiącym, iż «Rzeczpospolita Polska jest państwem świeckim, neutralnym w sprawach religii i przekonań». Kształtujący się w Rzeczypospolitej Polskiej model państwa świeckiego wynikał odtąd nie tylko z ustawy o gwarancjach, ale musiał uwzględniać odpowiednie treści normatywne przepisów konkordatu, który po ratyfikacji stał się aktem prawnym porządku prawnego Rzeczypospolitej Polskiej o wyższej mocy obowiązywania niż ustawa o gwarancjach"23. Trybunał Konstytucyjny uznał zatem wyższą moc obowiązywania Konkordatu niż ustawy z dnia 17 maja 1989 r. o gwarancjach wolności sumienia i wyznania ${ }^{24}$. W związku z tym stanowisko takie powinno odnosić się także do innych ustaw.

Podpisanie konkordatu nie zakończyło procesu formowania się nowego modelu relacji między państwem a Kościołem Katolickim. Zdaniem Trybunału Konstytucyjnego takim momentem było dopiero ratyfikowanie konkordatu, które zamknęło okres formowania się nowego modelu stosunków między państwem a Kościołem Katolickim, który respektuje standardy demokratyczne, ale opiera się również na historycznych tradycjach ${ }^{25}$.

W ocenie Trybunału Konstytucyjnego w art. 25 ust. 3 Konstytucji przyjęto ujęcie modelu stosunków między państwem i innymi związkami wyznaniowymi takie jak w art. 1 konkordatu: „Szczególna pozycja Kościoła katolickiego, wynikająca z zawarcia traktatu, została potwierdzona w Konstytucji RP (art. 25 ust. 4). Konstytucja, określając model stosunków między państwem a kościołami i innymi związkami wyznaniowymi (art. 25 ust. 3), przyjęła, co do istoty, to samo ujęcie, które zostało zamieszczone w art. 1 konkordatu, podkreślające poszanowanie wzajemnej niezależności i autonomii państwa i kościoła, każdego w swojej dziedzinie (zakresie) oraz współdziałania dla dobra człowieka i dobra wspólnego"26. Trybunał Konstytucyjny wskazał zatem explicite na przejęcie w art. 25 ust. 3 Konstytucji tego samego ujęcia, co w art. 1 Konkordatu zawierającego uznanie ,zasady poszanowania wzajemnej niezależności i autonomii państwa i kościoła, każdego w swoim zakresie" i jednocześ-

23 Tamże.

24 Ustawa z dnia 17 maja 1989 r. o gwarancjach wolności sumienia i wyznania, tekst jedn. Dz. U. z 2017 r., poz. 1153.

25 Por. wyrok Trybunału Konstytucyjnego z dnia 2 grudnia 2009 r., U 10/07.

26 Tamże. 
nie związanej z nią zasady „współdziałania dla dobra człowieka i dobra wspólnego".

Można zatem stwierdzić, że ujęcie art. 25 ust. 3 Konstytucji nałożyło się na ujęcie art. 1 Konkordatu. Nałożenie to miało charakter wzmacniająco-rozszerzający, albowiem je wzmocniło (w kontekście hierarchii źródeł prawa powszechnie obowiązującego) i jednocześnie rozszerzyło (w kontekście zakresu obowiązywania tej normy w odniesieniu do wszystkich związków wyznaniowych).

\section{ZASADA POSZANOWANIA AUTONOMII I NIEZALEŻNOŚCI JAKO ELEMENT RELACJI PAŃSTWA I ZWIĄZKÓW WYZNANIOWYCH}

Relacje między państwem i związkami wyznaniowymi opierają się zdaniem Trybunału Konstytucyjnego na takich zasadach - zgodnie z art. 25 Konstytucji - jak: „- równouprawnienie kościołów i innych związków wyznaniowych; - bezstronność władz publicznych w sprawach przekonań religijnych, światopoglądowych i filozoficznych; - swoboda wyrażania przekonań religijnych, światopoglądowych i filozoficznych w życiu publicznym; - poszanowanie autonomii oraz wzajemnej niezależności każdego w swoim zakresie w relacjach między państwem a kościołami i związkami wyznaniowymi; - współdziałanie państwa z kościołami i związkami wyznaniowymi dla dobra człowieka i dobra wspólnego;-konsensualna regulacja stosunków między państwem a kościołami i związkami wyznaniowymi: na podstawie umów, a w wypadku Kościoła katolickiego - umowy międzynarodowej ze Stolicą Apostolską"27. Tym samym relacje te aktualnie opierają się nieodłącznie na zasadzie poszanowania autonomii i niezależności Kościoła i państwa każdego w swoim zakresie. Zasada ta stanowi element konstytutywny tych relacji.

Uznanie zasady poszanowania autonomii i niezależności w art. 25 ust. 3 Konstytucji ma istotne znaczenie w kontekście ustroju. Trybunał Konstytucyjny podzielił stanowisko doktryny w zakresie nadania art. 25 postaci zasady ustrojowej. Zdaniem Trybunału Konstytucyjnego: „Trafnie

27 Wyrok Trybunału Konstytucyjnego z dnia 14 grudnia 2009 r., K 55/07 (Dz. U. z 2009 r. Nr 218, poz. 1702; OTK ZU z 2009 r. Nr 11A, poz. 167; Legalis nr 180038). 
podnosi się w doktrynie, że skoro regulacji instytucjonalnej pozycji kościołów i związków wyznaniowych, zamieszczonej w art. 25 Konstytucji, nadano postać zasady ustrojowej, to interpretacja wszystkich innych postanowień konstytucyjnych musi być prowadzona w sposób «przyjazny» tym zasadom, a więc w sposób zapewniający im maksymalną możliwość realizacji. To istotnie pewna zaleta przyjętej metody dyspersji oraz nadania art. 25 Konstytucji statusu zasady ustrojowej (zob. L. Garlicki, op. cit., s. 6)"28. W tym zakresie Trybunał Konstytucyjny podzielił część stanowiska doktryny ${ }^{29}$. Kwestia przyjętej metody dyspersji w kontekście wytycznych wykładni systemowej zostanie przedstawiona w dalszej części artykułu.

Jednocześnie Trybunał Konstytucyjny zauważył, że poszczególne państwa mogą przyjmować w ramach własnego ustroju różne modele relacji państwa i związków wyznaniowych. Na podstawie wyroku Trybunału Konstytucyjnego z dnia 2 grudnia 2009 r.: „Trybunał pragnie też podkreślić, że przedmiotem rozbieżności lub sporów, dotyczących regulacji problematyki wyznaniowej we współczesnych konstytucjach (demokratycznych), co jest widoczne również w Polsce, nie są standardy demokratyczne dotyczące indywidualnych gwarancji wolności sumienia i wyznania. Te bowiem są ujmowane wszędzie w sposób w miarę jednolity. Państwa demokratyczne różnią się natomiast istotnie co do wyboru modelu instytucjonalnego, będącego konsekwencją przyjęcia określonego modelu relacji między państwem a kościołami i innymi związkami wyznaniowymi" ${ }^{30}$. Ze stanowiska Trybunału Konstytucyjnego wynika, że choć aspekt indywidualny wolności religijnej na płaszczyźnie konstytucji demokratycznych państw jest dosyć zbliżony, to zauważyć można w tym aspekcie różnorodność modeli relacji państwa i związków wyznaniowych. Trybunał Konstytucyjny nie odniósł się jednak w tym wywodzie do treści współczesnych konkordatów, które współtworzą system prawny poszczególnych państw jako dwustron-

28 Wyrok Trybunału Konstytucyjnego z dnia 2 grudnia 2009 r., U 10/07. Por. także wyrok Trybunału Konstytucyjnego z dnia 8 czerwca 2011 r., K 3/09 (Dz. U. z 2011 r. Nr 129, poz. 748; OTK ZU z 2011 r. Nr 5A, poz. 39; Legalis nr 329965); Sobczyk 2017, 215.

29 Przegląd stanowisk doktryny w tym zakresie przedstawił szeroko M. Olszówka jednocześnie aprobująco odnosząc się do zastosowanej metody dyspersji. Por. Olszówka 2016, 145.

30 Wyrok Trybunału Konstytucyjnego z dnia 2 grudnia 2009 r., U 10/07. 
ne umowy międzynarodowe, ze swej istoty bardziej szczegółowo regulujące kwestie wyznaniowe niż umowy multilateralne o zasięgu uniwersalnym lub terytorialnym. Liczne konkordaty zawierane z poszczególnymi państwami demokratycznymi wskazują na dosyć powszechne stosowanie przyjaznego modelu rozdziału ${ }^{31}$.

Trybunał Konstytucyjny wskazał, że w Polsce przyjęcie zasady poszanowania autonomii i wzajemnej niezależności państwa i kościołów oraz innych związków wyznaniowych stanowi wyraz kompromisu między różnymi propozycjami określenia relacji stosunków państwa i związków wyznaniowych $^{32}$. Warto podkreślić, że zdaniem samego Trybunału osiągnięty kompromis uwzględnia międzynarodowe standardy w tym zakresie ${ }^{33}$. Tym samym analizowana zasada nie ma charakteru wyjątkowego.

\section{WYKŁADNIA ZASADY POSZANOWANIA AUTONOMII I NIEZALEŻNOŚCI}

Jak już wskazano, zdaniem Trybunału Konstytucyjnego przyjęcie przedmiotowej zasady wpisuje się w międzynarodowe standardy państw demokratycznych, z czym wiąże się również nadanie odpowiedniego kierunku wykładni tej zasady. Zgodnie z wyrokiem Trybunału Konstytucyjnego z dnia 14 grudnia 2009 r.: „Prawodawca konstytucyjny, ustanawiając regulacje dotyczące wolności sumienia i religii, dążył w szczególności do

31 Por. Poniatowski 2016, 88-109.

32 Por. wyrok Trybunału Konstytucyjnego z dnia 14 grudnia 2009 r., K 55/07. Warto jedynie na marginesie dodać, że w orzecznictwie Trybunału Konstytucyjnego odnaleźć można również analizę autonomii i niezależności nie tylko związków wyznaniowych, ale również innych podmiotów, takich jak spółdzielnie (por. wyrok Trybunału Konstytucyjnego z dnia 31 lipca 2015 r., K 41/12, Dz. U. z 2015 r., poz. 1158; OTK ZU z 2015 r. Nr 7A, poz. 102; Legalis nr 1310331), związki zawodowe (por. wyrok Trybunału Konstytucyjnego z dnia 26 kwietnia 2018 r., K 6/15, Dz. U. z 2018 r., poz. 830; OTK ZU z 2018 r. Seria A, poz. 24; Legalis nr 1760159), a nawet sam Trybunał Konstytucyjny (por. wyrok Trybunału Konstytucyjnego z dnia 9 marca 2016 r., K 47/15, Dz. U. z 2018 r., poz. 1077; OTK ZU z 2018 r. Seria A, poz. 31; Legalis nr 1406600), przy czym ich autonomia i niezależność wynika oczywiście z innych podstaw aniżeli w przypadku związków wyznaniowych.

33 Por. wyrok Trybunału Konstytucyjnego z dnia 14 grudnia 2009 r., K 55/07. Jak trafnie zwraca uwagę M. Muszyński, prawo międzynarodowe ma coraz szerszy zakres w stosunku do klasycznego ujęcia tego prawa. Por. Muszyński 2018, 249-271. 
urzeczywistnienia demokratycznych standardów wyrażonych m.in. w Międzynarodowym Pakcie Praw Obywatelskich i Politycznych, otwartym do podpisu w Nowym Jorku dnia 19 grudnia 1966 r. [...] oraz w Konwencji o ochronie praw człowieka i podstawowych wolności, sporządzonej w Rzymie dnia 4 listopada 1950 r. [...]. Z tego względu treść przepisów konstytucyjnych dotyczących wolności sumienia i religii powinna być interpretowana przy uwzględnieniu wymienionych instrumentów międzynarodowych oraz rozwiniętego na ich podstawie orzecznictwa." ${ }^{34}$ Tym samym interpretacja analizowanej zasady powinna być dokonywana przy uwzględnieniu nie tylko instrumentów międzynarodowych, ale również rozwiniętego na ich podstawie orzecznictwa.

Poza ogólnym kierunkiem wykładni w orzecznictwie Trybunału Konstytucyjnego odnaleźć można również klasyczne elementy wykładni prawa. Po pierwsze, Trybunał Konstytucyjny odniósł się do analizy językowej takich pojęć jak ,autonomia” i „niezależność”. W tym kontekście warto przytoczyć stanowisko Trybunału zawarte w wyroku z dnia 14 grudnia 2009 r., zgodnie z którym: „Pojęcia autonomii i niezależności odnoszą się do dwóch aspektów tej samej sytuacji. Pojęcie autonomii odnosi się do sfery wewnętrznej i oznacza prawo do samodzielnego rozstrzygania o sprawach danego podmiotu, natomiast niezależność dotyczy relacji zewnętrznych i jest rozumiane jako brak podporządkowania innym podmiotom (zob. D. Dudek, Równouprawnienie kościołów i związków wyznaniowych na tle konstytucyjnych zasad prawa wyznaniowego, (w:) Prawo wyznaniowe w systemie prawa polskiego, red. A. Mezglewski, Lublin 2004, s. 207). Zasada poszanowania autonomii i wzajemnej niezależności oznacza m.in. prawo wspólnot religijnych do samodzielnego decydowania o swoich sprawach wewnętrznych, w szczególności określania treści swojej wiary, struktur organizacyjnych oraz obsadzania stanowisk kościelnych"35. Takie stanowisko Trybunału odpowiada dosyć szeroko przyjmowanemu $\mathrm{w}$ doktrynie prawa wyznaniowego rozróżnieniu pojęć autonomii i niezależności ${ }^{36}$. W konsekwencji Trybunał wprost odniósł się do stanowiska L. Garlickiego i stwierdził: „W doktrynie zwraca się uwagę,

\footnotetext{
34 Wyrok Trybunału Konstytucyjnego z dnia 14 grudnia 2009 r., K 55/07.

35 Tamże.

36 Por. Krukowski 2005, 151-154.
} 
że wymieniona zasada zakłada uznanie odrębności zakresu działania państwa i wspólnot religijnych oraz wykluczenie ingerencji. Każdy z wymienionych podmiotów ma własną sferę działania, organy władzy publicznej nie ingerują w sprawy wewnętrzne wspólnot a organy władzy kościelnej nie ingerują w sprawowanie władzy państwowej (zob. L. Garlicki, op. cit., s. 17)"37. Tym samym oba pojęcia wzajemnie się uzupełniają i jednocześnie ustalają własną strefę działania organów władzy publicznej i organów władzy kościelnej.

W aspekcie wykładni historycznej, jak już wcześniej wskazano, zdaniem Trybunału uznanie zasady poszanowania autonomii i niezależności było wynikiem kompromisu, jak i odejściem od tzw. muru separacji. Warto w tym miejscu dodatkowo przytoczyć stanowisko sędzi E. Łętowskiej, która nawet w zdaniu odrębnym do cytowanego wyroku Trybunału Konstytucyjnego z dnia 14 grudnia 2009 r. stwierdziła: „Finansowanie z budżetu państwa wyższych uczelni prowadzonych przez kościoły czy związki wyznaniowe uważam za dopuszczalne co do zasady. Jest to bowiem wyraz «przyjaznego rozdziału», jaki wyraża Konstytucja z 1997 r., określając model stosunków państwo - kościoły. Model ten jest przyjazny dla współdziałania między państwem i kościołami (związkami wyznaniowymi), w przeciwieństwie do Konstytucji z 1952 r., która w tym względzie hołdowała zasadzie «muru separacji»".

Tym samym można uznać, że w ocenie Trybunału Konstytucyjnego dyrektywy wykładni wskazują na „przyjazny”, a nie „wrogi” kierunek wykładni analizowanej zasady. Warto dodać, że w odrębnej sprawie zgodnie ze stanowiskiem Prokuratora Generalnego - powołującym się na stanowisko doktryny prawa wyznaniowego - w art. 25 ust. 3 Konstytucji została wyrażona ,idea przyjaznego, a nie wrogiego, oddzielenia kościoła od państwa". Do tego stanowiska nie odniósł się jednak w tej sprawie Trybunał Konstytucyjny z uwagi na umorzenie postępowania z przyczyn formalnych ${ }^{38}$.

Trybunał Konstytucyjny podkreśla również, że przedmiotowa zasada wymaga zastosowania wykładni systemowej, w szczególności z uwagi na

37 Wyrok Trybunału Konstytucyjnego z dnia 14 grudnia 2009 r., K 55/07.

38 Por. postanowienie Trybunału Konstytucyjnego z dnia 14 listopada 2007 r., K 20/06 (OTK ZU z 2007 r. Nr 10A, poz. 138; Legalis nr 95831). 
przyjęcie metody dyspersji (rozrzucenia) przepisów konstytucyjnych, regulujących materię wolności sumienia i wyznania, która nie wpływa jednak na hierarchię przepisów konstytucyjnych ${ }^{39}$. Trybunał Konstytucyjny wprost stwierdził, że wykładnia systemowa nabiera szczególnego znaczenia wobec tak przyjętej metody regulacji ${ }^{40}$.

W orzecznictwie Trybunału Konstytucyjnego wskazuje się na konieczność odniesienia się zarówno do pozostałej treści ustępu 3 art. 25 Konstytucji, całego art. 25 Konstytucji, art. 53 Konstytucji, jak również do innych artykułów Konstytucji. Można w tym miejscu wysnuć wniosek, że wykładnia systemowa powinna być stopniowa i dokonywana przy uwzględnieniu tych zakresów.

W pierwszym aspekcie należy wskazać, że zgodnie z wyrokiem TK z dnia 14 grudnia 2009 r.: ,Zasada autonomii i niezależności musi być interpretowana w kontekście konstytucyjnej zasady współdziałania państwa oraz kościołów i związków wyznaniowych dla dobra człowieka i dla dobra wspólnego, wyrażonej w art. 25 ust. 3 in fine. Uznanie odrębnych sfer działania państwa i wspólnot religijnych nie oznacza, że sfery te są całkowicie rozłączne. Istnieją obszary wspólne dla obu tych rodzajów podmiotów. W dziedzinach tych państwo i wspólnoty religijne powinny współpracować ze sobą dla dobra człowieka i dla dobra wspólnego (zob. L. Garlicki, op.cit., s. 16). Do obszarów wspólnych dla państwa oraz wspólnot religijnych zalicza się m.in. szkolnictwo (zob. L. Garlicki, op.cit., s. 17). Współdziałanie państwa oraz wspólnot religijnych może mieć m.in. formę pomocy finansowej i może obejmować m.in. dotowanie przez państwo szkół wyższych prowadzonych przez te wspólnoty" "11. Stanowisko takie odpowiada modelowi separacji skoordynowanej, w ramach której zasada poszanowania autonomii i niezależności oraz zasada współdziałania wzajemnie się uzupełniają ${ }^{42}$.

Wykładni zasady poszanowania autonomii i niezależności nie należy według Trybunału Konstytucyjnego zawężać wyłącznie do art. 25 ust. 3 Konstytucji. Zgodnie z wyrokiem Trybunału Konstytucyjne-

\footnotetext{
39 Por. wyrok Trybunału Konstytucyjnego z dnia 2 grudnia 2009 r., U 10/07.

40 Por. tamże.

41 Wyrok Trybunału Konstytucyjnego z dnia 14 grudnia 2009 r., K 55/07.

42 Por. Krukowski 2008, 76.
} 
go z dnia 2 grudnia 2009 r.: „Bezstronność władz publicznych w Rzeczypospolitej Polskiej, o której mowa w art. 25 ust. 2, w kontekście autonomii i wzajemnej niezależności, o której mowa w art. 25 ust. 3, oraz równouprawnienia kościołów i innych związków wyznaniowych (art. 25 ust. 1), nie może więc - zdaniem Trybunału - oznaczać faktycznej równości instytucjonalnej między kościołem rzymskokatolickim, dominującym w społeczeństwie polskim pod względem liczby wyznawców, a innymi kościołami i związkami wyznaniowymi" ${ }^{43}$.

W ramach wykładni systemowej należy w pierwszej kolejności wskazać, że art. 25 i 53 Konstytucji mają zdaniem Trybunału Konstytucyjnego charakter komplementarny: „W szczególności, zamieszczenie art. 25 Konstytucji, regulującego zwłaszcza zagadnienia instytucjonalne wolności sumienia i wyznania, nie oznacza, iż usytuowanie tego artykułu w rozdziale I («Rzeczpospolita»), wśród zasad ustrojowych, przesądza o priorytecie art. 25 nad art. 53 Konstytucji w procesie wykładni Konstytucji. Art. 25 i art. 53 mają charakter komplementarny i winny być rozpatrywane jako pewna całość" 44 . Tym samym zasada poszanowania autonomii i niezależności powinna podlegać wykładni nie tylko w kontekście całego art. 25 Konstytucji, ale również w odniesieniu do art. 53 Konstytucji.

Choć art. 25 i 53 Konstytucji mają według Trybunału Konstytucyjnego charakter komplementarny, to jednocześnie w przedmiotowym orzecznictwie podkreśla się konieczność dokonywania wykładni systemowej, również z uwzględnieniem innych artykułów Konstytucji, które implicite odnoszą się do zagadnień wyznaniowych. Zgodnie z wyrokiem Trybunału Konstytucyjnego z dnia 2 grudnia 2009 r.: „Przyjęta metoda regulacji powoduje również, że szczególnego znaczenia nabiera wykładnia systemowa; powyższe artykuły Konstytucji winny być interpretowane w szerszym kontekście konstytucyjnym, a zwłaszcza w kontekście: ogólnych przepisów ustrojowych; postanowień wstępu do Konstytucji (odniesienie do Boga, do tradycji polskich, do zasady pomocniczości); art. 2, określającego zasadę demokratycznego państwa prawnego; art. 30 (zasada godności osoby ludzkiej); art. 32, określającego prawo do równego traktowania przez władze publiczne i wprowadzającego zakaz dyskryminacji «z ja-

43 Wyrok Trybunału Konstytucyjnego z dnia 2 grudnia 2009 r., U 10/07.

44 Tamże. 
kiejkolwiek przyczyny»; art. 31 ust. 3 dotyczącego ogólnych (wspólnych) zasad ograniczania praw i wolności, który to przepis znajduje swą konkretyzację w art. 53 ust. 5 (stanowiącym lex specialis na tle art. 31 ust. 3)"45.

Ponadto dla wykładni systemowej znaczenie mają artykuły, które nie mają charakteru typowo wyznaniowego. Zgodnie z wyrokiem Trybunału Konstytucyjnego z dnia 14 grudnia 2009 r.: „Dla oceny zgodności zaskarżonych ustaw z zasadą poszanowania autonomii państwa oraz kościołów i związków wyznaniowych oraz ich wzajemnej niezależności - każdego w swoim zakresie - istotne znaczenie ma także treść art. 70 ust. 5 Konstytucji. Ten ostatni przepis zapewnia autonomię szkół wyższych na zasadach określonych w ustawie. Wbrew twierdzeniom wnioskodawców dotacje dla szkół wyższych prowadzonych przez podmioty prywatne nie naruszają konstytucyjnie gwarantowanej autonomii szkół wyższych, przy czym należy wyjaśnić, że za takie naruszenie nie może być uważany nadzór władz publicznych nad legalnością wydatkowania przez te szkoły środków publicznych" ${ }^{46}$.

W kontekście wykładni funkcjonalnej należy przypomnieć, że zasada ta określa relacje między państwem i związkami wyznaniowymi. Zdaniem Trybunału Konstytucyjnego uchwalenie Konstytucji z dnia 2 kwietnia 1997 r. oznaczało zakończenie przebudowy dotychczasowego modelu tych relacji i wprowadzenie formuły państwa świeckiego gwarantującego demokratyczne standardy wolności sumienia i wyznania w warunkach pluralizmu, neutralności i bezstronności państwa wobec religii ${ }^{47}$. Funkcjonowanie analizowanej zasady niewątpliwie przyczynia się do jednoczesnego funkcjonowania tej formuły.

Ponadto na kanwie wyroku Trybunału Konstytucyjnego z dnia 2 grudnia 2009 r. można dojść do wniosku, że wykładnia przedmiotowej zasady powinna być dokonywana przy uwzględnieniu aksjologii konstytucyjnej skoro, jak już wskazano, wytyczne tej wykładni odnoszą się m.in. do treści preambuły czy też uznania godności osoby ludzkiej.

Warto również dodać, że niezwykle istotne wskazanie w kontekście funkcjonowania sądów ma stanowisko Trybunału Konstytucyjnego zawar-

\footnotetext{
45 Tamże.

46 Wyrok Trybunału Konstytucyjnego z dnia 14 grudnia 2009 r., K 55/07.

47 Por. wyrok Trybunału Konstytucyjnego z dnia 2 grudnia 2009 r., U 10/07.
} 
te w wyroku z dnia 14 grudnia 2009 r., zgodnie z którym: „Z drugiej strony w myśl zasady autonomii i niezależności, prawo wspólnot religijnych nie obowiązuje bezpośrednio w porządku państwowym, choć może i powinno być brane pod uwagę przy wydawaniu przez organy władzy publicznej rozmaitych rozstrzygnięć dotyczących wspólnot religijnych"48. Jako przykład można wskazać uznawanie w orzecznictwie sądowym wymogów określonych w prawie kanonicznym w zakresie alienacji, których naruszenie skutkuje nawet nieważnością konkretnych czynności prawnych ${ }^{49}$.

\section{ZAKRES POSZANOWNIA AUTONOMII I NIEZALEŻNOŚCI}

Istotą zasady poszanowania autonomii i niezależności jest to, że przysługuje ona państwu i związkom wyznaniowym w odpowiednim dla nich zakresie. Określenie własnego zakresu jest w praktyce trudne do zdefiniowania. Oczywiście są obszary, w których autonomia i niezależność państwa i związków wyznaniowych wydaje się być bezsporna, np. kwestia bezpieczeństwa ruchu lotniczego określana przepisami powszechnie obowiązującymi przez państwo czy też kwestie dotyczące przesłanek ważności małżeństwa kanonicznego określane prawem kanonicznym przez Kościół.

Jednakże pojawiają się również zagadnienia sporne ${ }^{50}$. Niektóre z tych zagadnień były przedmiotem analizy Trybunału Konstytucyjnego. Za przykład spraw wchodzących w zakres zarówno sfery państwowej, jak i odpowiednio związków wyznaniowych, można podać funkcjonowanie szkół i uczelni wyznaniowych ${ }^{51}$. W przypadku tych ostatnich warto wskazać na wyrok Trybunału Konstytucyjnego z dnia 14 grudnia 2009 r., zgodnie z którym: „W opisanym kontekście, w ocenie Trybunału Konstytucyjnego, dotacje dla uczelni kościelnych nie ograniczają autonomii i niezależ-

48 Wyrok Trybunału Konstytucyjnego z dnia 14 grudnia 2009 r., K 55/07.

49 Por. także uchwała Sądu Najwyższego z dnia 19 grudnia 2008 r., III CZP 122/08 (Legalis nr 112754).

50 Warto zwrócić uwagę na historyczny charakter tych sporów także w samym prawie kanonicznym, co obrazuje chociażby treść Corpus Iuris Canonici. Por. Uruszczak 2014, 251-258.

51 W doktrynie dodatkowo wskazuje się, że uczelniom wyznaniowym przysługuje odpowiednia autonomia. Por. Krajczyński 2016, 54-55. 
ności Kościoła katolickiego w jego zakresie działania, nie ograniczają również autonomii i niezależności państwa od kościoła w sferze właściwej państwu. Stanowią natomiast jedną z możliwych form realizacji przez państwo ciążących na nim zadań publicznych w zakresie szkolnictwa wyższego i urzeczywistniają konstytucyjne prawo dostępu do tego szkolnictwa"52. O spornym charakterze tego zagadnienia świadczy nie tylko zainicjowanie tego postępowania, ale również zdanie odrębne sędzi TK Ewy Łętowskiej, której zdaniem ustawa z dnia 5 kwietnia 2006 r. o finansowaniu Papieskiego Wydziału Teologicznego w Warszawie z budżetu państwa $^{53}$, ustawa z dnia 5 kwietnia 2006 r. o finansowaniu Papieskiego Wydziału Teologicznego we Wrocławiu z budżetu państwa ${ }^{54}$ oraz ustawa z dnia 5 kwietnia 2006 r. o finansowaniu Wyższej Szkoły Filozoficzno-Pedagogicznej „Ignatianum” w Krakowie z budżetu państwa ${ }^{55}$ są niezgodne z art. 25 ust. 1 i 3 w związku z art. 32 Konstytucji ${ }^{56}$. Stanowisko zawarte w tym zdaniu odrębnym zostało uzasadnione zarzutem braku powszechności oferty edukacyjnej oraz brakiem równouprawnienia. Natomiast w kontekście braku respektowania granicy, jaką stwarza art. 25 ust. 3 Konstytucji, zdaniem E. Łętowskiej: „Działalność edukacyjna w zakresie szkolnictwa wyższego jest realizowana zarówno przez kościoły (związki wyznaniowe), które prowadzą własne uczelnie, jak i przez system państwowego szkolnictwa wyższego. Kulturotwórcza i edukacyjna funkcja wyższych uczelni wyznaniowych uzasadnia konstytucyjną dopuszczalność ich finansowania - pod warunkiem wszakże, że dotyczy to kształcenia w zakresach i kierunkach, w których misja kościołów i państwa są niejako równoległe. Taka równoległość nie zachodzi w sferze objętej autonomią kościołów. To wyklucza moim zdaniem spod pojęcia kształcenia (i finansowania tego kształcenia z budżetu) w zakresie «współdziałania dla dobra wspólnego» np. finansowanie kształcenia o profilu czysto religijnym, kształcenie duchownych (kapłanów) poszczególnych wyznań, a więc finansowanie semi-

52 Wyrok Trybunału Konstytucyjnego z dnia 14 grudnia 2009 r., K 55/07.

53 Dz. U. z 2006 r. Nr 94, poz. 648.

54 Dz. U. z 2006 r. Nr 94, poz. 649.

55 Dz. U. z 2006 r. Nr 94, poz. 650.

56 Por. zdanie odrębne sędzi TK Ewy Łętowskiej do wyroku Trybunału Konstytucyjnego z dnia 14 grudnia 2009 r., K 55/07. 
nariów duchownych" ${ }^{57}$. Jednakże stanowisko to nie zostało zaaprobowane $\mathrm{w}$ wywodzie prawnym zawartym w uzasadnieniu przedmiotowego wyroku Trybunału Konstytucyjnego.

Powyższy spór obrazuje, że w swej istocie to właśnie określenie zakresu autonomii i niezależności jest najbardziej skomplikowane i należy przypuszczać, że w przyszłości Trybunał Konstytucyjny będzie wydawał orzeczenia w kontekście interpretacji określeń „każdego w swoim zakresie”, o którym mowa w art. 25 ust. 3 Konstytucji, jak i „każde w swej dziedzinie", o którym mowa w art. 1 Konkordatu. Dotychczasowe orzecznictwo Trybunału Konstytucyjnego w tym zakresie nie jest zbyt bogate. Tym bardziej zatem warto (mimo przyjętego modelu państwa świeckiego w wersji tzw. separacji skoordynowanej) zwrócić uwagę na dorobek kanonistyki i przedstawiane w niej argumenty, które nie posiadają charakteru teologicznego, a wskazują na przesłanki wyodrębnienia zakresu funkcjonowania wspólnoty politycznej i religijnej.

Zakres autonomii i niezależności odnosi się nie tylko do państwa, ale także wspólnot politycznych, których jest ono członkiem. Przykładowo Trybunał Konstytucyjny orzekł, że domeną prawa wspólnotowego nie jest regulowanie relacji między państwem a kościołami i związkami wyznaniowymi ${ }^{58}$.

\section{ZAKOŃCZENIE}

Analiza orzecznictwa Trybunału Konstytucyjnego w kontekście zasady poszanowania autonomii i niezależności wskazuje, że orzecznictwo wprost odnoszące się do przedmiotowej zasady nie jest jeszcze zbyt rozległe. Koresponduje ono jednak z wieloma innymi orzeczeniami, które pośrednio odnoszą się czy to do zasady poszanowania autonomii i niezależności, czy też ogólnie relacji państwa i związków wyznaniowych, które zdaniem Trybunału mają charakter złożony i wzajemnie się uzupełniający. Tym samym orzeczenia explicite odnoszące się do zasady poszanowania

57 Tamże.

58 Wyrok Trybunału Konstytucyjnego z dnia 11 maja 2005 r., K 18/04 (Dz. U. z 2005 r. Nr 86, poz. 744, OTK ZU 2005, Nr 5A, poz. 49, Legalis nr 68382). 
autonomii i niezależności powinny być analizowane w szerszym kontekście aniżeli w zakresie wywodu prawnego zawartego w uzasadnieniach pojedynczych orzeczeń.

W orzecznictwie tym dotychczas pomija się kanoniczną proweniencję tej zasady i jej interpretacji, która w samym Kościele trwa blisko dwa tysiąclecia, przy uwzględnieniu nie tylko argumentacji teologicznej, ale również aksjologiczno-prawnej mającej już charakter uniwersalny. Rozważania Trybunału Konstytucyjnego w zakresie pochodzenia tej zasady kończą się w zasadzie na debacie nad kształtem Konstytucji i zmianą modelu relacji państwa i związków wyznaniowych.

Zdaniem Trybunału Konstytucyjnego przedmiotowa zasada ma charakter zasady ustrojowej, współtworząc z pozostałymi zasadami aktualny model relacji państwo-Kościół. Jednocześnie w orzecznictwie Trybunału odnaleźć można wykładnię analizowanej zasady w aspekcie językowym, historycznym, systemowym, jak i funkcjonalnym

W swoim orzecznictwie Trybunał Konstytucyjny wskazuje na relacje Konstytucji z 1997 r. i Konkordatu z 1993 r., choć nie zwraca uwagi na dosyć powszechną praktykę zawierania przez Stolicę Apostolską konkordatów z państwami świeckimi, a nawet niechrześcijańskimi państwami wyznaniowymi. Jednocześnie zasada poszanowania autonomii i niezależności w ocenie Trybunału Konstytucyjnego stanowi wręcz standard międzynarodowy.

Warto zauważyć, że orzecznictwo Trybunału Konstytucyjnego nie jest szerokie w kontekście określenia zakresu autonomii i niezależności, co jest w praktyce najbardziej skomplikowane. Należy przypuszczać, że w przyszłości Trybunał Konstytucyjny z zachowaniem zasady skargowości będzie wydawał orzeczenia w kontekście interpretacji określeń „każdego w swoim zakresie", o którym mowa w art. 25 ust. 3 Konstytucji, jak i „każde w swej dziedzinie”, o którym mowa w art. 1 Konkordatu.

Z kolei dla praktyki sądowej niezwykle ważne jest stanowisko Trybunału Konstytucyjnego, zgodnie z którym, choć prawo poszczególnych związków wyznaniowych nie obowiązuje explicite w porządku państwowym, to może i powinno być ono brane pod uwagę przy wydawaniu przez organy władzy publicznej rozmaitych rozstrzygnięć dotyczących tych związków. 


\section{BIBLIOGRAFIA}

Borecki, Paweł. 2002. Koncepcje stosunków między państwem a związami wyznaniowymi w projektach i postulatach konstytucyjnych. Warszawa: Elipsa.

Borecki, Paweł. 2004. „Geneza konstytucyjnej regulacji stosunków Państwo Kościół. Droga do art. 25 Konstytucji RP z 2 kwietnia 1997 r.” W: Prawo wyznaniowe w systemie prawa polskiego. Materiały I Ogólnopolskiego Sympozjum Prawa Wyznaniowego (Kazimierz Dolny, 14-16.1.2003 r.), red. Artur Mezglewski, 49-66. Lublin: Wydawnictwo KUL.

Borecki, Pawel. 2008. Geneza modelu stosunków Państwo-Kościót w Konstytucji RP.

Warszawa: Wydawnictwo Sejmowe.

Krajczyński, Jan. 2016. „Prawo oświatowe a autonomia szkół wyznaniowych w zakresie nauczania i wychowania”. Przeglad Prawa Wyznaniowego 8: 47-67.

Krukowski, Józef. 1993. „Katolickie postulaty konstytucyjne”. Rocznik Teologiczny 1: 319-330.

Krukowski, Józef. 2008. Polskie prawo wyznaniowe. Warszawa: LexisNexis.

Krukowski, Józef. 2013. Kościelne prawo publiczne. Prawo konkordatowe. Lublin: Towarzystwo Naukowe KUL.

Krukowski, Józef. 2019. „Konkordat między Stolicą Apostolską a Rzecząpospolitą Polską 1993-1998”. W: Konkordaty Polskie. Historia i teraźniejszość, red. Józef Krukowski, 147-411. Lublin: Towarzystwo Naukowe KUL.

Leszczyński, Paweł Adrian. 2001. Zagadnienia wyznaniowe w Konstytucji RP. Warszawa: Wydawnictwo Naukowe „Semper”.

Leszczyński, Paweł Adrian. 2014. „Instytucjonalno-polityczne aspekty ładu światopoglądowego w Polsce - geneza, teraźniejszość i przesłanki zmian”. Przeglad Prawa Wyznaniowego 6: 19-43.

Němec, Damian. 2011. Concordat Agreements between the Holy See and the Post-Communist Countries (1990-2010). Leuven-Paris-Walpole: Peeters.

Olszówka, Marcin. 2016. Wpływ Konstytucji RP z 1997 roku na system źródet prawa wyznaniowego. Warszawa: Oficyna Wydawnicza Uczelni Łazarskiego. Pietrzak, Michał. 1993. „Państwo i Kościół w obecnej i przyszłej konstytucji polskiej”. Rocznik Teologiczny 1: 281-299.

Pietrzak, Michał. 1997. „Rozdział Kościoła i Państwa - modele i spór o ujęcie normatywne w nowej konstytucji". W: Podstawowe prawa jednostki i ich sądowa ochrona, red. Leszek Wiśniewski, 104-126. Warszawa: Wydawnictwo Sejmowe. Poniatowski, Michał. 2012. Zasada poszanowania wzajemnej niezależności i autonomii Kościoła i państwa w prawie kanonicznym i jej recepcja w konkordatach i konstytucjach wspótczesnych państw. Warszawa: mps. 
Poniatowski, Michał. 2014. „Dualizm religijno-polityczny w pierwszym tysiącleciu chrześcijaństwa". W: Reddite ergo quae sunt Caesaris Caesari et quae sunt Dei Deo. Księga jubileuszowa dedykowana Księdzu Profesorowi Józefowi Krukowskiemu z okazji 50-lecia pracy naukowej, red. Mirosław Sitarz, Piotr Stanisz, Henryk Stawniak, 211-237. Lublin: Towarzystwo Naukowe KUL.

Poniatowski, Michał. 2016. „Proclamation of the principle of mutual respect for the independence and autonomy of Church and State in modern concordats". Annuarium Iuris Canonici 3: 88-109.

Sobczyk, Paweł. 2004. „Udział przedstawiciela Episkopatu Polski w pracach Komisji Konstytucyjnej Zgromadzenia Narodowego nad artykułem 25 Konstytucji Rzeczypospolitej Polskiej z dnia 2 kwietnia 1997 r." W: Ecclesia et Status. Księga Jubileuszowa z okazji 40-lecia pracy naukowej Profesora Józefa Krukowskiego, red. Antoni Dębiński, Krzysztof Orzeszyna, Mirosław Sitarz, 859-887. Lublin: Towarzystwo Naukowe KUL.

Sobczyk, Paweł. 2005. Kościół a wspólnoty polityczne. Warszawa: Santiago.

Sobczyk, Paweł. 2013. Konstytucyjna zasada konsensualnego określenia stosunków między Rzeczapospolitą Polska a Kościołem katolickim. Warszawa: Oficyna Wydawnicza ASPRA-JR.

Sobczyk, Paweł. 2017. „Podstawowe zasady relacji państwo-Kościół w nauczaniu Kościoła katolickiego i w prawie polskim. Zbieżności i rozbieżności”. W: Kościól a naród i państwo w perspektywie 1050. rocznicy Chrztu Polski. Historia i teraźniejszość, red. Józef Krukowski, Mirosław Sitarz, Ireneusz Dosz, 215-224. Lublin: Towarzystwo Naukowe KUL.

Stanisz, Piotr. 2015. „Konstytucyjne zasady określające relacje państwa z kościołami i innymi związkami wyznaniowymi: autonomia i niezależność oraz współdziałanie". W: Katolickie zasady relacji państwo-Kościół a prawo polskie, red. Józef Krukowski, Mirosław Sitarz, Henryk Stawniak, 159-185, Lublin: Towarzystwo Naukowe KUL.

Uruszczak, Wacław. 2014. „«Reddite quae sunt Caesaris Caesari et quae Dei Deo» w Corpus Iuris Canonici", W: Reddite ergo quae sunt Caesaris Caesari et quae sunt Dei Deo. Księga jubileuszowa dedykowana Księdzu Profesorowi Józefowi Krukowskiemu z okazji 50-lecia pracy naukowej, red. Mirosław Sitarz, Piotr Stanisz, Henryk Stawniak, 251-258. Lublin: Towarzystwo Naukowe KUL.

Zieliński, Tadeusz Jacek. 1997. „Klauzule prawnowyznaniowe jednolitego projektu konstytucji RP (Uwagi de lege fundamentale ferenda)". Państwo i Prawo 2: 81-98. 


\title{
THE PRINCIPLE OF RESPECT FOR THE AUTONOMY \\ AND MUTUAL INDEPENDENCE OF THE STATE AND CHURCHES AND OTHER RELIGIOUS ORGANIZATIONS IN THE JURISPRUDENCE OF THE CONSTITUTIONAL TRIBUNAL
}

\begin{abstract}
This article presents an analysis of the jurisprudence of the Constitutional Tribunal in relation to the principle of respecting the autonomy and mutual independence of the State and churches and other religious organizations. In the first part, the study focuses on the provenance of the principle in question, primarily taking its comparative aspect into account. Then the principle is presented as an element of the relationship between the State and religious organizations in the jurisprudence of the Constitutional Tribunal. The subsequent parts provide an interpretation of this principle and its scope in the jurisprudence of the Constitutional Tribunal. The article ends with a discussion of the most important conclusions.
\end{abstract}

Key words: autonomy; independence; Church-State relations; religious freedom; Church-State cooperation 